\title{
Seroprevalence of antibodies against rubella virus in pregnant women in Haiti
}

\author{
Olbeg Y. Désinor, ${ }^{1}$ Renette J. P. Ansèlme, ${ }^{1}$ Fernando Laender, ${ }^{2}$ \\ Calerbe Saint-Louis, ${ }^{1}$ and Jean Eddy Bien-Aimé ${ }^{1}$
}

Suggested citiation Désinor OY, Ansèlme RJP, Laender F, Saint-Louis C, Bien-Aimé JE. Seroprevalence of antibodies against rubella virus in pregnant women in Haiti. Rev Panam Salud Publica. 2004;15(3):147-50.

ABSTRACT Objective. To assess the seroprevalence of immunity to the rubella virus in pregnant women in Haiti attending the Obstetrics and Gynecology Department of the State University Hospital, in the capital city of Port-au-Prince, in order to help with the introduction of the rubella vaccine for the population and provide protection for women of reproductive age in the country. Methods. This cross-sectional study was done between February 2002 and May 2002. A total of 503 pregnant women were tested for rubella-specific immunoglobulin $G$ antibodies, using enzyme immunoassay; 8 of those women were later excluded because they did not know their age, leaving 495 women in the analysis.

Results. Of the 495 participants included in our analysis, 471 of them (95.2\%) were seropositive; only 24 of them (4.8\%) were seronegative (susceptible). A statistically significant difference ( $\mathrm{P}=0.02)$ was found in the rate of seronegativity for rubella virus between the pregnant women living in the Port-au-Prince area (17 of 426 women, or $4.0 \%)$ and those living in rural areas (7 of 69 women, or 10.1\%). In terms of age, 81 of the 495 (16.4\%) women were under 21 years old.

Conclusions. This study is an important first step in addressing the issue of prevalence of rubella virus infection among Haitian women and in dealing with the still-underrecognized public health problem of congenital rubella syndrome in Haiti. We recommend additional research that uses randomized sampling and includes a significant proportion of women from rural areas of the country.

Key words Rubella; rubella syndrome, congenital; pregnant women; immunization; immunization programs; Haiti.

Congenital rubella syndrome (CRS) has been associated with congenital cataracts, deafness, mental retardation, and cardiac defects (1). It is a sys-

\footnotetext{
1 State University Hospital, Port-au-Prince, Haiti. Send correspondence to: Olbeg Y. Désinor, PO Box 174, Port-au-Prince, Haiti.

2 Pan American Health Organization/World Health Organization Office, Port-au-Prince, Haiti.
}

temic disease that can be prevented by vaccination during infancy and adolescence (2). The Pan American Health Organization (PAHO) has encouraged the countries of the Western Hemisphere to include the vaccine in their vaccination programs $(3,4)$. Cuba and the islands of the English-speaking Caribbean have progressed in controlling this transmissible disease because of aggressive vaccination programs (3, 5). Nevertheless, Haiti is among the very few countries in the Region of the Americas without a vaccination program against rubella.

In Haiti a recent confirmed case of congenital rubella syndrome at the State University Hospital in Port-auPrince focused our attention on the severity and the underestimation of 
TABLE 1. Susceptibility for rubella virus of pregnant women in Haiti, according to age groups and Port-au-Prince area vs. rural areas, $2002^{a}$

\begin{tabular}{|c|c|c|c|c|c|c|c|c|c|c|c|c|c|}
\hline \multirow{3}{*}{$\begin{array}{c}\text { Age group } \\
\text { (yr) }\end{array}$} & \multirow{3}{*}{$\begin{array}{l}\text { No. of women } \\
\text { in each } \\
\text { age group }\end{array}$} & \multicolumn{4}{|c|}{$\begin{array}{l}\text { Port-au-Prince } \\
\quad(n=426)\end{array}$} & \multicolumn{4}{|c|}{$\begin{array}{l}\text { Rural areas } \\
\qquad(n=69)\end{array}$} & \multicolumn{4}{|c|}{$\begin{array}{l}\text { Haiti overall } \\
(n=495)\end{array}$} \\
\hline & & \multicolumn{2}{|c|}{ Immune } & \multicolumn{2}{|c|}{ Seronegative } & \multicolumn{2}{|c|}{ Immune } & \multicolumn{2}{|c|}{ Seronegative } & \multicolumn{2}{|c|}{ Immune } & \multicolumn{2}{|c|}{ Seronegative } \\
\hline & & No. & $\%$ & No. & $\%$ & No. & $\%$ & No. & $\%$ & No. & $\%$ & No. & $\%$ \\
\hline$<15$ & 1 & 1 & 100 & 0 & 0.0 & 0 & 0.0 & 0 & 0.0 & 1 & 100 & 0 & 0.0 \\
\hline $15-20$ & 80 & 72 & 94.7 & 4 & 5.3 & 4 & 100 & 0 & 0.0 & 76 & 95.0 & 4 & 5.0 \\
\hline $21-25$ & 147 & 120 & 96.8 & 4 & 3.2 & 21 & 91.3 & 2 & 8.7 & 141 & 95.9 & 6 & 4.1 \\
\hline $36-40$ & 42 & 33 & 97.0 & 1 & 3.0 & 7 & 87.5 & 1 & 12.5 & 40 & 95.2 & 2 & 4.8 \\
\hline $41-45$ & 12 & 9 & 100 & 0 & 0.0 & 3 & 100 & 0 & 0.0 & 12 & 100 & 0 & 0.0 \\
\hline Total & 495 & 409 & 96.0 & 17 & 4.0 & 62 & 89.9 & 7 & 10.1 & 471 & 95.2 & 24 & 4.8 \\
\hline
\end{tabular}

a From our original sample of 503 women who were tested, we excluded 8 women who did not know their age, leaving 495 women for the analysis.

this problem in the country. Recent estimates put the incidence of new cases of CRS in Haiti at between 163 and 440 per 100000 live births per year. That rate is high in comparison to the incidences of CRS that Jamaica, Trinidad, and the United States of America had in their prevaccination years (6). This is the first study of seroprevalence of rubella in pregnant women in Haiti.

\section{METHODS}

This is a cross-sectional study that was done between February 2002 and May 2002 at the Obstetrics and Gynecology Department of the State University Hospital. The State University Hospital is located in Port-au-Prince, the capital of Haiti, and it is the main referral health center for the country.

A convenience sample was used for the study. Five hundred and three pregnant women were tested from among patients attending the prenatal care outpatient service or giving birth in the State University Hospital Maternity Ward. From the 503 women, we excluded 8 of them who did not know their age, leaving a sample of 495 women for our analysis. (Because of illiteracy and a low level of education, some persons in Haiti do not know their age.)

Of the 495 women analyzed, 426 of them $(86.1 \%)$ came from the Portau-Prince area. The other 69 women $(13.9 \%)$ came from rural areas of the nine administrative departments of Haiti. Because the State University Hospital is the main referral health center in the country for all medical specialties, pregnant women may be referred to or may wish to attend the hospital.

Because of the high illiteracy rate in Haiti, an informed consent form was read aloud to each of the participants in Haitian Creole, the language spoken by all the people in the country. After asking and receiving answers to any questions she had, the woman indicated her consent by signing the form. A $2.5-\mathrm{mL}$ blood sample was drawn and then sent the same day to the Virology Laboratory of the State University Hospital. The sera were separated and stored at $-20{ }^{\circ} \mathrm{C}$ until tested for rubella.

Rubella-specific immunoglobulin G (IgG) antibodies were screened quantitatively using commercial enzyme immunoassay kits (Dade Behring, Marburg, Germany). Rubella IgG titers of 15 International Units/mL or greater were considered positive. For quality control testing, 40 sera were randomly selected and sent to the PAHO/ World Health Organization Caribbean Regional Epidemiological Center (CAREC) on the island of Trinidad. All the CAREC results matched the ones found at the State University Hospital Virology Laboratory.

The chi-square test was used to determine the statistical significance of any difference in the rates of rubella seronegativity (susceptibility) of pregnant women residing in Port-au-Prince and of pregnant women residing in rural areas of the country. A $P$ value of $<0.05$ was considered statistically significant.

\section{RESULTS}

From the total of 495 pregnant women tested and included in our analysis, 471 of them were seropositive $(95.2 \%)$, and 24 were seronegative $(4.8 \%)$. In terms of age, 81 of the 495 women $(16.4 \%$ of them) were less than 21 years old, 402 of them $(81.2 \%)$ were between the ages of 21 and 40, and 12 of them $(2.4 \%)$ were $41-45$ years old. As mentioned above, 426 of the 495 women were living in Port-au-Prince or the surrounding metropolitan area, and the other 69 patients were from rural regions of Haiti. Of the 69 women from the rural areas, 7 of them (10.1\%) tested seronegative, compared with 17 of the 426 women $(4.0 \%)$ living in the capital city (Table 1). The difference was statistically significant $(P=0.02)$. Among the 24 seronegative women, 15 of them $(62.5 \%)$ were less than 31 years old, that is, in their prime reproductive years.

\section{DISCUSSION}

Even with an overall low susceptibility (seronegativity) rate of $4.8 \%$, congenital rubella syndrome could still occur in Haiti. That happened, for ex- 
ample, in one region of Oman where only $4 \%$ of the women were susceptible $(7,8)$. Because our study population consisted of women who were attending the prenatal clinic or had come to give birth at the State University Hospital, a selection bias could be responsible for the $95.2 \%$ seropositivity rate that we found. Nevertheless, the relatively high cost of the rubella vaccine for the average Haitian and the low socioeconomic status of our patients made it very unlikely that they had received the vaccine. Rubella vaccine is given on a very limited basis by private practitioners in Port-au-Prince, and it is not included in the Expanded Program on Immunization of the Ministry of Health of Haiti. Indeed, information about any previous rubella immunizations of the women participating in the study was so unreliable that we researchers did not take it into account. A more realistic explanation for the $95.2 \%$ seropositivity of the pregnant women in the study is the widespread circulation of the rubella virus in the general population in Haiti.
Many countries in the developing world have reported relatively low rubella susceptibility rates compared to those for industrialized countries in their prevaccination periods (7). Earlier rubella outbreaks in Guyana and in Jamaica are proof of rubella virus circulation in the Caribbean area $(2,9)$. On the other hand, most of the women whom we tested live in crowded urban areas, where circulation of the rubella virus is easier than in rural areas. Studies done in Panama and Peru have found marked differences in estimates of rubella infection in urban and rural areas (10).

We found a statistically significant difference in the rate of seronegativity for rubella virus between the women residing in Port-au-Prince and those living in rural areas. Because of the low overall seronegativity, rubella vaccination efforts targeting children under 15 years old would be a less costly strategy for preventing CRS than would vaccinating large segments of the population, including women up to 45 years old.

\section{REFERENCES}

1. Prelub SR, Alford CA. Rubella. In: Remington JS, Klein JO, eds. Infectious diseases of the fetus and newborn infant. 3rd ed. Philadelphia: W.B. Saunders; 1990. Pp. 196-224.

2. Robertson SE, Cutts FT, Samuel R, DiazOrtega JL. Control of rubella and congenital rubella syndrome (CRS) in developing countries, part 2: vaccination against rubella. Bull World Health Organ. 1997;75:69-80.

3. Organisation panaméricaine de la Santé, Division des vaccins et de l'immunisation. Vaccination contre la rubéole des femmes en âge de procréer (Amériques). Bull Informatif du PEV. 2001;22(4):6.

4. Pan American Health Organization, Division of Vaccines and Immunization. Brazil accelerates control of rubella and prevention of con- genital rubella syndrome. EPI Newsl. 2002; 25(2):1-3.

5. Plotkin SA. Where rubella is still a problem. Pediatr Infect Dis J. 1999;18:575-6.

6. Golden N, Kempker R, Khator P, Summerlee $\mathrm{R}$, Fournier A. Congenital rubella syndrome in Haiti. Rev Panam Salud Publica. 2002;12(4): 269-73.

7. Cutts FT, Robertson SE, Diaz-Ortega JL, Samuel R. Control of rubella and congenital rubella syndrome (CRS) in developing countries, part 1: burden of disease from CRS. Bull World Health Organ. 1997;75(1):55-68.

8. World Health Organization, Expanded Programme on Immunization. Rubella outbreak, Oman. Wkly Epidemiol Rec. 1994;69(45):333-7.
We recommend additional research using randomized sampling and including a significant proportion of women from rural areas. Even with the limitations with the data that we collected, our study is an important first step in addressing the issue of seroprevalence of rubella virus antibodies in Haitian women and in dealing with the still-underrecognized public health problem of congenital rubella syndrome in the country.

Acknowledgments. We are grateful to the interns, residents, and nurses in the Obstetrics and Gynecology Department of the State University Hospital, particularly to nurse Bernadette Yolle Garçon; Dr. Ronald Cornely, Chief of the OB/GYN Department; and Dr. Elsie Michel Salnave, Chief of the Laboratory Department. We also want to thank the Office of PAHO/ WHO in Port-au-Prince for providing the rubella kits and for its support in the testing process, as well as Grier Page for his contribution to the statistical analysis.
9. World Health Organization, Expanded Programme on Immunization. Immunization in the English-speaking Caribbean. Wkly Epidemiol Rec. 1996;71:217-23.

10. Cutts FT, Vynnycky E. Modelling the incidence of congenital rubella syndrome in developing countries. Int J Epidemiol. 1999; 28(6):1176-84.

Manuscript received 25 June 2003. Revised version accepted for publication on 30 December 2003. 
RESUMEN Objetivo. Determinar la seroprevalencia de la inmunidad al virus de la rubéola en mujeres embarazadas que se atienden al Departamento de Obstetricia y Ginecología del Hospital de la Universidad Estatal, en Puerto Príncipe, capital de Haití, a fin de

Seroprevalencia de anticuerpos contra el virus de la rubéola en mujeres embarazadas de Haití contribuir a introducir la vacunación de la población contra la rubéola y proteger a las mujeres en edad reproductiva en el país.

Métodos. Este estudio transversal se realizó entre febrero y mayo de 2002. Se evaluó la presencia de anticuerpos de tipo IgG específicos contra la rubéola en 503 embarazadas mediante un inmunoensayo enzimático. Posteriormente se excluyó a 8 mujeres debido a que no sabían su edad.

Resultados. De las 495 participantes estudiadas, 471 (95,2\%) tenían seropositividad; solo 24 de ellas $(4,8 \%)$ mostraron seronegatividad (susceptibilidad). Se encontraron menos mujeres seronegativas entre las residentes de Puerto Príncipe (17 de 426, 4,0\%) que entre las residentes de zonas rurales $(7$ de $69,10,1 \%)(P=0,02)$. En relación con la edad, $81(16,4 \%)$ de las 495 mujeres embarazadas estudiadas eran menores de 21 años. Conclusiones. Con este estudio se da el primer paso hacia evaluar la prevalencia de la infección por el virus de la rubéola en mujeres haitianas y hacia el enfrentamiento de un problema de salud que todavía no ha sido reconocido en toda su magnitud: el síndrome de la rubéola congénita en Haití. Se recomienda emprender estudios adicionales con muestreos aleatorios que abarquen una fracción significativa de mujeres provenientes de zonas rurales. 